\title{
今までの日本，今からの日本
}

\section{水野 博之}

はじめに

最近，日米間をしきりに往来している．往来していて痛感するのは，米国の活力，日本の 沈滞である。しかし今から 10 年ほど前は事態はまったく逆であった. 1980 年代はまさにくジ ヤパン・アズ・ナンバー・ワン〉の時代であった．その象徴的事件が〈日米半導体問題〉で あったであろう. 1980 年代の終わり，半導体ユーザ協議会の代表としてこの䦗題に当たった 私にとって，この問題はいまだに昨日のようで方る. 問題の基本はく米国製の半導体製品を 買え，買うものがない〉の押し問答であって，まさに事態は全く逆，そのものであった。

この間, 僅か 10 年のうちに一体, 何が起きたのか, この反省なしに, 次の時代の日本はな いのであろう.

\section{0 年代の特質}

日本の輝いていた 1980 年代についてはすでに多くのことが語られているが,その特質を一 言にしていえば〈キャッチ・アップ戦略の成功〉といえるのではないか. 明治以来, 西欧列 強に追いつくことをその国是としてきた日本が,まさにその目標を達成したのが 1980 年代で あった，といってよい．マラソンにおいてセカンド・グループより，ファースト・グループ へと追いつくことが大変な仕事であるように，一言にして〈キャッチ・アップ〉というが， それはまた，大変なことであった，そこには，日本人の国民性と，何より幸運があったこと

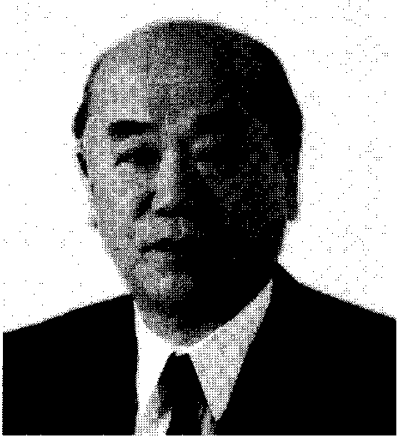

第37代会長（1996年度）, 高知工科大学 を忘れてはならないであろう。それでは, 日本のつちかった〈キャッチ・アップの条件〉と幸運とは一体，何であったのか？

\section{キャッチ・アップのための条件}

世界の後進国がすべて日本のように躍んで短期日のうちに世界一流のレベルに達しうるか，というと，なかなか，そうもい かない, ということからも日本のもつ特質が理解されるであろう．その第一は, 〈日本民族の均一性〉であろう. 明治立国以来 いろいろなことがあったが, 一つの目標に対してよき意味にも悪しき意味にも一致協力するという日本人の均一性は, ベクト ルとして合成されたとき大きな力を発揮して来たのであった，第二にはく低貨金〉である．均一によく教育されたこの国の民 は，その貧しさの故に，まことによく㗢いた。このことはいま特筆されてよいであろう。しかしながら，これら我为力だけ では物事は成り立たなかったであろう．日本が力強い躍進をするためにはまことに幸運ともいうべき環境があった。 それは躍 進の条件となる技術，大きくいえば〈知的財産〉がたや寸く手に入った，ということである。たやすくという意味は二つあっ て，一つは〈使用させない〉といったケースは絶無とはいわないまでも，殆どなかったし，二つには，その使用料もまことに 安かったということである. 日米半導体問題の最中, インテルのノイスがいみじくも語った言葉がまさにこのことを象徴して いる：〈まさか, 日本がこれだけやるとは思いもしなかったなあ。こんなことになるのなら，プレナ一特許をそう簡単に使わ すのではなかった〉.プレナー特許というのは集積回路の基本特許でインテルの所有になるものである.

三つにはこれら環境をうまく利用できるインフラ・ストラクチャーがあった，ということであろう。このなかには教育制度 の普及もあるだろうし，道路その他，社会的に日本全体をつなぎうるコミュニケーションの手段なども含まれるであろう．

\section{日本の研究}

残念なことにこのようなく日本成功の研究〉は日本においてよりも，外国において行われた，とくに米国においては，いわ ゆる多〈の〈ジャパン・プログラム〉がスタートし，米国民の警鐘を鳴らし続けたのであったそその間，日本は〈夜郎自大〉 となり，21 世紀は日本の時代と勝手に決めこんでいたのであった．多くの官民による日本研究の結果，米国が到達したのが， 〈情報化時代〉なるコンセプトである。ここでは，日本の得意とするハードではなくソフトが，さらには，知的財産を含む情 報の価值が何よりも高く評価されるのである。いわば, 有形のものより無形のもの, 大きくはコンセプトとも呼ぶべき構想力 がその社会を動かす原動力となる。ハードはそれを実現するための手段であり，ッールなのである。

このような美学ともいえる構想を思案し, 実行しているのが〈産官学の協力体制〉である. 特に〈産学の協力体制〉はまこ とに至れりつくせりであってそこに米国の英知を見るのである.

\section{産学協同体制}

言うまでもなく，歴史的に，学問を学ぶべき学校と，利益を目標とする産業界とはその成立している立場は異っている。し かしながらこっちが両々相俟って人類の進歩を支えて来たのもまた事塞である。このことが最も顕著に現われたのが産業革命 においてであった．現在，グラスゴー大学における最も有名な教授職の一つには〈ジェームス・ワット〉の名がつけられてい 
ることからもこのことは理解出来ようというものである。率直にいってワット自身は学問的というより実務的な人間であった ようで，彼には発明家という名称がろさわしいであろう。その彼の試行錯譟的なやり方に対して，何とか学問的な支持を支え ようと努力した人達がいて，それらの成果が熱力学的体系を形づくっていくのである．その代表的例が, カルノーによって思 考された〈理想的熱機関〉の考察であろう。この孤独で純粋な思考は後に〈エントロピー〉なる概念に集約され，人類が達し た一つの基本的理念となっていくのである，先進国においてはそのような産学協力のあり方は当然といえば当然であった，誰 にも解けない難問があればそれに挑戦するのは人間の本能であるから．残念なことに後進国はこうはいかない，文字通り後か ら進むだけに学問はともすれば〈解釈論〉となり自らの発想より，先進国の発想をもとに進められることになる。結果として 〈独創性〉より〈知識の量〉が問題となるようになった，日本の入学試験はそのもっともよき例であろう。

\section{1 世紀を目指して}

ここまでくれば間題は明白であろう．1980年代は日本の時代であった.このときに日本のたどった道(それが意識的であっ たかどうかは別にして）いわゆる〈キャッチ・アップ〉の手法はいま，後進国の歩むべき一つの典型をなしている，しかしな がら，いかなる優れた手法も環境の変化とともに疲労し，合わなくなっていく。このことを冷静に判断して，次の日本を構想 しなくてはならないであろう。そのためには 1980 年代に米国がそうであったように, 日本国内から澎湃なる新しい声が上らな いといけないであろう。日本の総智を集めた議論が〈産, 官, 学〉のすべての分野において起きないといけないであろう。議 論を行うに当っては次のことが大切であろう.

1 議論は建設的でなくてはならない.いたずらに他をけなすようなことでは前向きのものにならないであろう。特に個人的 な問題と全体的なものとははっきり分けるべきだ。これだけの大変動である。個々にはたまたま，めぐり合わせとして矢面に たたざるを得ない人達もあろう。とかくそのような個人が革新への矢面に立つことになることが多いが，このような紏弾は朴 を見て森を見ないの幣におちいること，フランス革命の例に見る通りである.

2 議論は夕テとヨコのつながりにおいて行われるべきである.タテのつながりにおける議論と同時に，ヨコの連係において も議論は深められていかないといけない，そのためには，なんらかの形での〈産官学〉の仕組みを考えていかないといけない であろう．新しい組織をつくるのもよいが, 考えてみれば，〈産官学〉の仕組みがいまもつともうまく働いているのはく学会〉 である、学会にもいろいろあってなかには古き良き（？）アカデミズムにこりかなまっているようなのもあるがそそんなのは 例外として，いままで〈科学，技術〉といった共通の地盤で，そうしてそれだけで機能していたこの場をもっと広く大きく拡 げていくことだ。学会のなかにそのよjな分科会を扔くのもよいであろう．要は学会をもっと開いた場にして，そこで大いに 知力をたたかわしたらよいと思われる。

3 以上のことは民間中心に行わ林なてはならないであろう。ここでいう民間とは，〈政治〉と区別した意味において用いら れている。もちろん結果はすべて政治におよぶ。それだけに既存の立場をはなれて議論することが大切であるう。

このよjに考えてくると，いま，本当の意味でく日本における民主主義〉が問われているのである，私はこのような議論を 通じて日本の民主主義はきたえられ，かつまたその過程で次の時代の〈新しい展望〉がひらけていくものと確信している。

\section{本会の歴史から}

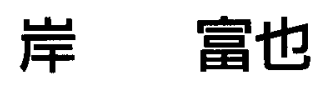

2000 年に当たっての本誌の企画に原稿の依頼をいただいたが，過ぎりせ紀の回顧も，来 るべき世紀への展望も，これらを述べることは固より筆者の任ではない．本全は創立以来， 今世紀の三分の二を歩んできた。偶々，1993 年，創立 60 周年に際して筆者が「60 年史」の 編纂に携わる機会を得たので，編纂の余滴のようなものを記して，責を塞ぎない。

昭和の初期, 第一次世界大戦の不況もようやく薄らざ, 国を挙げて工業振興の気運が高ま るなかで, 我が国の化学工業は重化学工業を中心とした第二次の興隆期を迎えようとしてい た。こに水力発電による豊富な電力を資源として利用するという社会的要請を背景として， 電気化学工業を中心とした本格的な重化学工業が我が国にもたらされた。この気運のなかで, 電気化学の学理の進步と, 電気化学工業の発展の中心となるべき本学会が誕生した. 学会か ら加藤与五郎, 亀山直人の両泰斗らと, 産業界加当時気鋭の起業家たち, 森䀽昶, 石川一 郎, 鈴木忠治, 棚橋寅五郎, 佐野隆一らが会の創設に参画した。これらの産学にわたる巨人 たちの紏合は，歴史的に稀有のことであり，またこのことが本会の伝統の形成に大きな影響 を及ばしている。

創設から終戦までの本会の歴史の約四分の一は, 我が国の 15 年戦争の時代と重なり, 重化 学工業の隆盛と, 敗戦によって灰燼に帰すまでの戦争を抜きにしては語ることが出来ない。

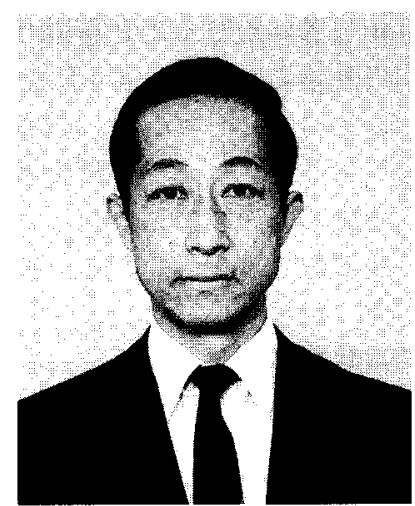

第 38 代会長 (1997 年度), 慶應義塾大学 